\title{
USING VOCABULARY NOTEBOOK AND PAVE STRATEGIES TO DEVELOP AL-AZHAR EFL SECONDARY STAGE STUDENTS' VOCABULARY LEARNING AND RETENTION Walaa Al-Adle Abd-Raboh Ali
}

\author{
A Teacher of English
}

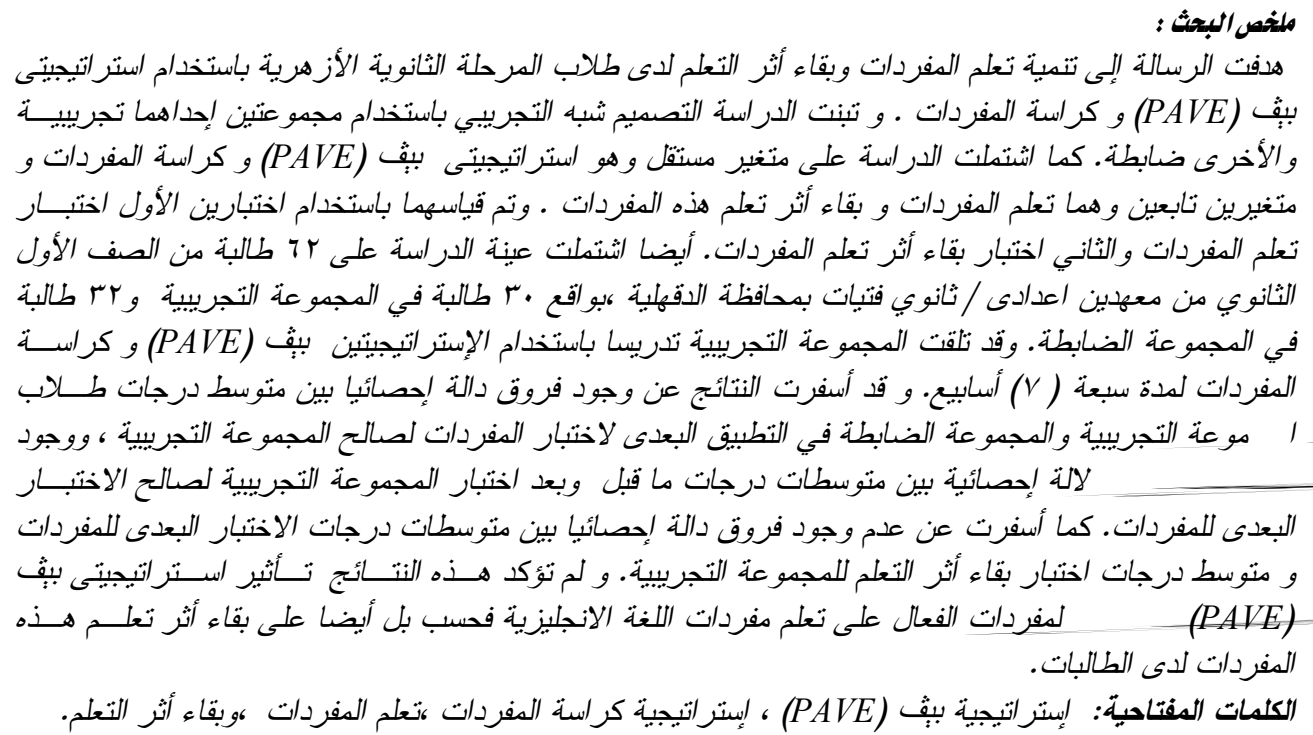

The current study aimed at developing vocabulary learning and retention of Al- Azhar secondary stage students by using PAVE and Vocabulary Notebook teaching strategies. It adopted a quasi-experimental design employing two groups; experimental and control. The design variables were measured by a Vocabulary Learning Test (VLT) and a Retention Test. The sample consisted of 62 first year female students of two Preparatory / Secondary Institutes for girls in Dakahliya Governorate. Instruments included a vocabulary learning test and a vocabulary retention test. Results revealed that there is a statistically significant difference between the mean score of the experimental and control group students on the post vocabulary test in favor of the experimental group. In addition, a statistically significant difference was found between the mean score of the experimental group pre and post vocabulary testing in favor of the post one. Finally, no statistically significant difference was found between the mean score of the experimental group post and retention vocabulary tests. These results showed that PAVE and Vocabulary Notebook strategies had a positive effect not only on the students' vocabulary learning but also on the students' vocabulary retention.

Keywords: PAVE Strategy, Vocabulary Notebook Strategy, Vocabulary Learning,

\section{Introduction:}

Vocabulary learning is the fastest growing area of second language acquisition and the heart of language teaching in terms of syllabuses organization, learner performance evaluation, and the provision of learning resources (Yoshii \& Flaitz, 2002). Students can not express their ideas, communicate effectively, learn about new concepts or improve their reading comprehension without developing their vocabulary. Vocabulary is the glue that holds stories, ideas and content together, making comprehension accessible for them. Students who have large vocabularies can understand new ideas and concepts more quickly and acquire academic success than 
students with limited vocabularies (Sedita 2005).

Shen (2003) confirms that vocabulary teaching should be dynamic and should take into account the various dimensions of the mental lexicon. On the other hand, it is necessary to use strategies to facilitate lexical consolidation in their memories. Therefore, learning words needs to involve a wide range of skills. This implies that it is difficult to isolate vocabulary learning strategies from one another (P.191). Language learners try to remember as many words as possible but they often cannot. Improving their capacity to remember new terms and expressions, emotions, concentrations and attentions is very important. Association or linking new information with old information is a tool to retain new words meaning effectively. One of the best and simplest ways to do this is simply to review what they have learned regularly. It is also important to learn words in their context which helps their brain to form images and associate the word to other words. Also if they link a given word with an image, they will remember it better (Lampariello, 2012).

Lampariello's ways (2012) to retain new word meanings are found in some vocabulary learning strategies such as PAVE strategy and keeping vocabulary notebooks. PAVE which stands for Prediction, Association, Verification and Evaluation is an effective vocabulary strategy used for increasing students' vocabulary skills (Howell, 2012). The second strategy is keeping a personal vocabulary notebook. Keeping a vocabulary notebook is a cognitive strategy. A vocabulary notebook is a kind of a personal dictionary; learners record the words with their meanings and any other important aspects of the word seemed important. Vocabulary notebooks are effective tools for students to take charge of, organize and manage their vocabulary learning (Walters \& Bozkurt, 2009).

\section{Review of Literature}

During the past three decades, vocabulary attracts the attention of many researchers to express its importance for second/foreign language acquisition. So, it becomes the subject of several research works and it is broadly asserted that vocabulary acquisition should be part of the syllabus design (Fazeli, 2012). For example, Nation (2001) described the relationship between vocabulary knowledge and language use as integrant. Vocabulary knowledge enables language use and language use leads to an augment in vocabulary knowledge.

\section{Vocabulary acquisition and retention}

Vocabulary learning is a

complicated process in which several skills are involved. These skills are vocabulary acquisition, vocabulary retention, and vocabulary transfer (Schneider et al., 2002). According to Nordquist (2017), "The process of learning the words of a language is referred to as Vocabulary Acquisition "." Retention is keeping vocabulary in Long-term memory and retrieving it for meaningful use in appropriate contexts" (Daloglu, Baturay, \& Yildirim, 2009, p. 203).

Peter (2002) identified major elements of a vocabulary course which help students acquire and retain vocabulary. These components are: 1.meating new vocabulary for the first time, 2.establishing previously met words, 3- enriching previously met vocabulary, 4-developing vocabulary strategies and 5. developing fluency with known vocabulary.

Importance of using vocabulary learning strategies

Shams \& Rahimy (2012, p.141) mentioned that vocabulary learning strategies mostly called VLSs are among significant issues in English language learning which have been taken into 
consideration during previous decades. EFL/ESL learners have always complained about forgetting whatever vocabularies they have memorized. In order to suggest solutions to this problem or even present some useful guidelines to both learners and teachers in this regard, many studies have been made in the field of Vocabulary Learning (VL)". Vocabulary learning strategies help learners to be able to control their own learning so that they can take more responsibility for their studies (Nation 2001).

Vocabulary notebook and PAVE strategies:

\section{A) Vocabulary notebook strategy}

Vocabulary notebook is a flexible method which is used for gathering information about words that allows for the deep processing of those words. It also encourages noticing, retrieving, generating and engaging learners actively with words and word learning. It forces the multiple exposures to each word necessary for retention as well (Taveggia, 2013).

Importance of Vocabulary Notebooks

Vocabulary notebook develops autonomous learning and enhances long term memory. It also increases lexical competence, develops effective learning strategies, and can outlive the classroom. A vocabulary notebook helps the development of metacognitive awareness and promotes strategy transfer to other learning spheres (Centenario, 2013). In addition, Walters \& Bozkurt (2009, P.404) asserted that use of the notebook in class work also supports the use of consolidation strategies, as students return to the notebook to retrieve words, use the words in classroom activities, and share their words with their classmates.

Vocabulary notebook procedures Salama (2016: 56, p.57) mentioned the following procedures of vocabulary notebook:

1. Provide a description, explanation, or example of the new term.
- Ask students what they already know, and build upon that prior knowledge.

- Focus on defining the term.

2. Ask students to restate the description, explanation, or example in their own words.

- Go back and provide additional examples.

- Allow students to discuss the term with a partner or in a small group if possible.

3. Ask students to construct a picture, symbol, or graphic representation of the term. Students create their representation in the "Draw" section of the organizer.

- Provide examples of studentse drawings and your own drawings that are rough but that represent the ideas. Model, model, model.

- Allow students, at first, to work together.

- Suggestions for non-linguistic representations: draw the actual thing, draw a symbol, dramatize the term, and draw an example.

4. Engage students periodically in activities that help them add to their knowledge of the terms in their notebooks.

- Allow students to revise their initial description/definition or picture.

\section{Vocabulary Notebook Formats \\ Vocabulary Notebook with Pictures} It is a student-made notebook mainly focuses on pictures made by students. Using pictures is a very interesting way to obtain meanings and improve students learning (Nosratinia, Sarmadi \& Shakeri, 2013). Sams (2011) has asserted that "It is experienced drawing or applying pictures roots the items in students' mind and one is more likely to be able to visualize and retain an image which has been personally created" (p. 17). 
Vocabulary Notebooks with Definitions Notebook with Definitions is a student-made notebook which focuses on definitions and other information in a dictionary. Students can form notebooks by writing vocabulary definitions and using them in meaningful contexts. A dictionary can be an excellent source to use in discovering meanings of unfamiliar words, particularly for determining the appropriate meaning of words that have multiple, or specific, technical definitions (Nosratinia, Sarmadi \& Shakeri, 2013).

Studies related to vocabulary notebook strategy

Kömüra*\& Özdemira (2015) examined the effects of keeping vocabulary notebooks on productive academic vocabulary growth. A pre-post vocabulary test was administered to two groups of the first year ELT students at Mugla Sitki Koçman University. Both groups used the same materials but the participants of the experimental group were asked to keep vocabulary notebooks. The treatment lasted eight weeks. The findings showed that the experimental group made more progress than the control group especially in terms of word formation section which leads to a productive vocabulary knowledge.

Vela \& Rushidi (2016) examined the effect of vocabulary notebooks on EFL students' vocabulary acquisition and students' responsibility of their own learning. Three groups of Intermediate level students from the South East European University Language Center were participated in the study and followed the same course material and syllabus over a four week period. The treatment group kept vocabulary notebooks but the other two control groups didn't keep vocabulary notebooks. Results of vocabulary tests showed that the treatment group's scores were significantly more successful than the control groups. These findings proved that vocabulary notebooks are an effective tool that promotes vocabulary acquisition as well as learner autonomy.

\section{B) PAVE strategy}

(Prediction, Association, Verification and Evaluation)

PAVE strategy is one of many interesting strategies that can be used in teaching vocabulary (SUSILO, 2016). Seminole County Public Schools (2016) considered PAVE strategy as a vocabulary learning strategy that helps students to predict the meaning of unknown word by using context clues. Then they use their dictionary to verify it. It also encourages them to create a personal visual clue to help them remember the definition.

\section{Importance of PAVE strategy}

PAVE strategy is a great way to use dictionaries properly, actively and collaboratively. It also helps students remember the words better. English teachers can also use PAVE vocabulary strategy for helping the students to be more motivated in learning (Susilo, 2016). PAVE is an effective vocabulary strategy used for increasing students' vocabulary skills. It helps students recall previous learned words and begin to use them as building blocks for the next unit's vocabulary. It also allows students to check the dictionary definition against the context in which the word appeared terms (Howell, 2012).

\section{Procedures of Teaching PAVE}

According to (Miami, 2000) procedures of PAVE strategy are:

1. Introduce the P.A.V.E. procedure with a fairly easy word and then have students practice with more difficult words.

2. Write the sentence or context in which a new word appears.

3. Write the word again (to emphasize the focus word) and predict a meaning from the context.

4. Write a sentence that demonstrates understanding of the word's meaning. 
5. Check the word's definition in a dictionary and write the definition.

6. Examine the sentence from step three and write a better one if necessary.

7. Draw an image to help remember the meaning by creating an associative link.

8. Repeat steps one through three using a more difficult word and then students complete steps four through six together as a whole-class activity.

9. Have each student complete one word individually and share with the class.

10. Complete a few more words individually or in small groups until the procedure is internalized.

11. Encourage students to use the procedure as they locate when they read independently.

\section{Studies related to $\mathrm{PAVE}$ strategy}

Mistique (2014) examined the extent to which reading comprehension will be improved when graphic organizers are used to increase vocabulary knowledge for seven middle school students with learning disabilities. He used two types of graphic organizers: the PAVE map and "Own the Word". Interpreting the pre-post survey and the vocabulary pre- post test results, findings showed a significant increase in vocabulary knowledge as well as reading comprehension.

In addition, Susilo (2016) explored whether there is a significant difference on students' achievement taught by using PAVE strategy and who were not. The population was all the third grade students of SD Negeri 182 Palembang in academic year 2012/2013 with total number 100 students. The result of the study showed that there was a significant difference on students' vocabulary achievement taught PAVE strategy and those who were not. There was also significant difference posttest on students' vocabulary achievement taught PAVE strategy. This research might be useful for teachers because it can help students remember new words and it is more stimulating in teaching and learning process.

\section{Statement of the problem}

Based on the literature review and pilot study results, it can be concluded that students are not doing well in learning vocabulary which in turn negatively affects their EFL learning.

In view of the many challenges facing the secondary institute EFL female students in learning English and vocabulary in particular, the current study aimed at investigating the effect of keeping vocabulary notebooks and PAVE strategies on developing students' vocabulary learning and retention.

\section{Questions}

This study attempted to answer the following major question

How can using vocabulary notebook and PAVE strategies contribute to developing students' vocabulary learning and retention? This main question leads to the following subquestions:

1- What is the effect of using vocabulary learning strategies (vocabulary notebook and PAVE) on developing EFL vocabulary learning of first year secondary AlAzhar Institute students?

2- What is the effect of using vocabulary notebooks and PAVE strategies on developing EFL first year secondary Al- Azhar institute students' vocabulary retention?

\section{Hypotheses}

This study attempted to test the following hypotheses:

1. There is a statistically significant difference between the mean score of the experimental group students and the control group students on the post 
vocabulary test in favor of the experimental group.

2. There is a statistically significant difference between the mean score of the experimental groups pre-post vocabulary test in favor of the post test.

3. There is no statistically significant difference between the mean score of the experimental group's post and retention vocabulary tests.

\section{Significance}

This study may be significant in a number of ways:

1- Directing the attention of EFL teachers and the curriculum planners towards the importance of using vocabulary notebook and PAVE strategies to improve the students level in learning vocabulary and developing their retention as well.

2- Helping language learners implement PAVE strategies to achieve their academic goals.

3- Encouraging students to be selfindependent in discovering the meaning of the new words by following PAVE steps and copying them in their vocabulary notebook.

4- Raising students' awareness about the importance of adopting a vocabulary notebook since the primary stage.

\section{Delimitations}

The study was delimited to:

1. First year secondary students at Kom Bani Meras and Tanah preparatory/ secondary Al- Azhar Institutes for girls, Mansoura Directorate, Dakahlia, Egypt.

2. New vocabulary of four units from Hello! English for secondary schools, Year one, student's Book: Units (1, 2, 3 and 4) in the first term of the academic year (2017-2018).

3. Vocabulary notebook and PAVE strategies.

\section{Methodology \\ Design}

The current study used a quasiexperimental design for assessing the effect of using Vocabulary Notebook and PAVE strategies on developing vocabulary learning and retention. The study used two groups: a control group and an experimental group. The control group was taught the vocabulary of English text book of the $1^{\text {st }}$ year secondary stage (Hello!), 1 st semester from unit 1 to 4 through regular method. The experimental group was taught the same vocabulary through the vocabulary notebooks and PAVE teaching strategies.

\section{Participants}

Participants of the study comprised of (62) students enrolled in the 1st term of the 2017/ 2018 school year and divided into a control group (N: 32) from Tanah Prep. / Secondary Institute for girls and experimental group (N: 30) from Kom Bani Meras Prep. / Secondary Institute for girls.

\section{Instruments}

Two vocabulary tests were designed and used to measure the students' level in learning vocabulary: 1) Pre-post Vocabulary Learning test and 2) Vocabulary Retention test.

\section{Definition of terms}

PAVE

In this study, PAVE strategy was defined as a vocabulary strategy which helps learners to become more independent. Students predict the new word meaning, associate it with its context, look up the word in a dictionary to verify their meaning and then reevaluate their prediction. They also draw a personal association or symbol for the word to help them remember its definition.

\section{Vocabulary notebook}

A vocabulary notebook is a learning strategy used in and out of the class room in which learners can record the words they encounter, along with their 
meanings and any other aspects of the word seemed important to become easy for them to remember or use it.

\section{Vocabulary Development}

The following definition was adopted to serve the purpose of this study:

Vocabulary development is the process of widening students' vocabulary to learn the meaning of new words and concepts in various contexts and across all academic content areas.

\section{Retention}

The following definition was adopted to serve the purpose of this study:

Retention means students' ability to keep new words in mind for a long time and recall them easily.

Table (1): Results of t- test of the control and experimental groups on the post Vocabulary Learning Test

\begin{tabular}{|c|c|c|c|c|c|c|c|}
\hline VARIABLES & The group & $\begin{array}{l}\text { N.of } \\
\text { cases }\end{array}$ & Means & S.D & df & T.Value & Sig. \\
\hline \multirow{2}{*}{ ( Q1) } & Control & 32 & 2.875 & 0.8980 & \multirow{2}{*}{60} & \multirow{2}{*}{-7.192} & 0.01 \\
\hline & Experimental & 30 & 4.367 & 0.7184 & & & Sig. \\
\hline \multirow{2}{*}{ ( Q2) } & Control & 32 & 2.375 & 1.4701 & \multirow{2}{*}{60} & \multirow{2}{*}{-6.184} & 0.01 \\
\hline & Experimental & 30 & 4.333 & 0.9499 & & & Sig. \\
\hline
\end{tabular}

\begin{tabular}{|c|c|c|c|c|c|c|c|}
\hline \multicolumn{8}{|c|}{ Table continues } \\
\hline \multirow{2}{*}{ ( Q3) } & Control & 32 & 2.766 & 0.6089 & \multirow{2}{*}{60} & \multirow{2}{*}{-12.227} & 0.01 \\
\hline & Experimental & 30 & 4.583 & 0.5584 & & & Sig. \\
\hline \multirow{2}{*}{ ( Q4) } & Control & 32 & 2.328 & 1.6245 & \multirow{2}{*}{60} & \multirow{2}{*}{-5.737} & 0.01 \\
\hline & Experimental & 30 & 4.350 & 1.0760 & & & Sig. \\
\hline \multirow{2}{*}{ ( Q5) } & Control & 32 & 1.234 & 1.2951 & \multirow{2}{*}{60} & \multirow{2}{*}{-7.852} & 0.01 \\
\hline & Experimental & 30 & 3.433 & 0.8483 & & & Sig. \\
\hline \multirow{2}{*}{ ( Q6) } & Control & 32 & 2.219 & 1.1284 & \multirow{2}{*}{60} & \multirow{2}{*}{-6.032} & 0.01 \\
\hline & Experimental & 30 & 3.900 & 1.0619 & & & Sig. \\
\hline \multirow{2}{*}{ Total } & Control & 32 & 13.797 & 4.8006 & \multirow{2}{*}{60} & \multirow{2}{*}{-10.462} & 0.01 \\
\hline & Experimental & 30 & 24.967 & 3.4465 & & & Sig. \\
\hline
\end{tabular}

Results in table (1) show that the mean scores of the experimental group on test questions and the total of the test were bigger than those of the control group. They were 13.79 for the control group and 24.967 for the experimental group in the post-test of the VLT. Thus, these differences were in favor of the experimental group as indicated by T-value $(-10.462)$ which is significant at (.001) level and degree of freedom $(\mathrm{df})=60$.

\section{Results and discussions Testing the first hypothesis}

The first hypothesis stated that, "There is a statistically significant difference between the mean scores of the experimental group students and the control group students on the post vocabulary test in favor of the experimental group".

To investigate this hypothesis, the mean scores of the experimental and control group students in the post-test of VLT were compared and t-value for independent samples was calculated. The following table (1) illustrates the results concerning this hypothesis.
To conclude, the experimental group outperformed the control group in vocabulary learning. This result could be due to the use of PAVE and vocabulary notebook strategies in teaching vocabulary. So, these strategies proved to be better than the regular method in teaching vocabulary and in enhancing vocabulary acquisition.

Testing the second hypothesis of the study 
The second hypothesis indicated that, " There is a statistically significant difference between the mean score of the experimental groups pre-post vocabulary test in favor of the post test".

For testing this Hypothesis, the mean score of the experimental group

Table (2): Results of t- test of the Experimental group pre and post testing scores on the Vocabulary LearningTest

\begin{tabular}{|c|c|c|c|c|c|c|c|}
\hline VARIABLES & $\begin{array}{l}\text { The } \\
\text { group }\end{array}$ & $\begin{array}{l}\text { N.of } \\
\text { cases }\end{array}$ & Means & S.D & df & T.Value & Sig. \\
\hline \multirow{2}{*}{ ( Q1) } & pre - test & 30 & 2.850 & 0.7560 & \multirow{2}{*}{29} & \multirow{2}{*}{-9.706} & 0.01 \\
\hline & post - test & 30 & 4.3667 & 0.71840 & & & Sig. \\
\hline \multirow{2}{*}{ ( Q2) } & pre - test & 30 & 2.533 & 1.2590 & \multirow{2}{*}{29} & \multirow{2}{*}{-6.837} & 0.01 \\
\hline & post - test & 30 & 4.3333 & 0.94989 & & & Sig. \\
\hline \multirow{2}{*}{ ( Q3) } & pre - test & 30 & 2.650 & 0.4183 & \multirow{2}{*}{29} & \multirow{2}{*}{$\begin{array}{l}- \\
18.154\end{array}$} & 0.01 \\
\hline & post - test & 30 & 4.5833 & $\mathbf{0 . 5 5 8 3 7}$ & & & Sig. \\
\hline \multirow{2}{*}{ ( Q4) } & pre - test & 30 & 1.250 & 1.0064 & \multirow{2}{*}{29} & \multirow{2}{*}{$\begin{array}{l}- \\
15.869\end{array}$} & 0.01 \\
\hline & post - test & 30 & 4.3500 & 1.07599 & & & Sig. \\
\hline \multirow{2}{*}{ ( Q5) } & pre - test & 30 & 1.117 & 1.0803 & \multirow{2}{*}{29} & \multirow{2}{*}{$\begin{array}{l}- \\
12.973\end{array}$} & 0.01 \\
\hline & post - test & 30 & 3.4333 & 0.84826 & & & Sig. \\
\hline \multirow{2}{*}{ ( Q6) } & pre - test & 30 & 2.033 & 1.4735 & \multirow{2}{*}{29} & \multirow{2}{*}{-6.513} & 0.01 \\
\hline & post - test & 30 & 3.9000 & 1.06188 & & & Sig. \\
\hline \multirow{2}{*}{ Total } & pre - test & 30 & 12.433 & 3.9167 & \multirow{2}{*}{29} & \multirow{2}{*}{$\begin{array}{l}- \\
27.293\end{array}$} & 0.01 \\
\hline & post - test & 30 & 24.9667 & 3.44647 & & & Sig. \\
\hline
\end{tabular}

Results of table 2 indicate that there is a statistically significant difference between the mean scores of the pre-test $(\mathrm{X} 1=12.433)$ and post-test $(\mathrm{X} 2=24.9667)$ of the experimental group students in the overall VLT in favor of the post-test. The table also shows that the estimated t-value is highly significant at 0.01 level.

To show the extent of PAVE and vocabulary notebook strategies ' effect on the experimental group in the vocabulary learning, the "Effect Size" was estimated. " $\eta$ " was calculated using the following formula: (Affana, 2000:

42) $\eta^{2}=\frac{t^{2}}{t^{2}+d f}$

The following table (3) shows values of $\left(\eta^{2}\right)$ and the effect size of the treatment on developing vocabulary learning. students in the pre-test and post-test of VLT were compared and t-value concerning vocabulary learning development and the total score in the post- administration of the test is illustrated in table (2).

Table (3): The Effect Size of PAVE and Vocabulary Notebook teaching strategies in the Pre- and the Post Test of the Experimental Group

\begin{tabular}{|l|l|l|}
\hline Skill & $\eta^{\mathbf{2}}$ & Effect size \\
\hline ( Q1) & $0.76 \%$ & \\
\hline ( Q2) & $0.62 \%$ & High \\
\hline ( Q3) & $0.92 \%$ & High \\
\hline ( Q4) & $0.90 \%$ & High \\
\hline ( Q5) & $0.85 \%$ & High \\
\hline ( Q6) & $0.59 \%$ & High \\
\hline Total & $\mathbf{0 . 9 6 \%}$ & High \\
\hline
\end{tabular}

From the previous table 3 , values of $\left(\eta^{2}\right)$ for sub questions ranged from 0.59 and 0.92 and were 0.96 for the total score of the test. The previous values show the strong effect of PAVE and Vocabulary Notebook teaching Strategies on students' vocabulary learning. Therefore, the second hypothesis of the study is accepted. 
Testing the third hypothesis

The third hypothesis indicated that, " There is no statistically significant difference between the mean score of the experimental group's post and retention vocabulary tests".

Table (4): Results of t- test of the Experimental group post and retention testing scores

\begin{tabular}{|c|c|c|c|c|c|c|c|}
\hline VARIABLES & $\begin{array}{l}\text { The } \\
\text { group }\end{array}$ & $\begin{array}{l}\text { N.of } \\
\text { cases }\end{array}$ & Means & S.D & df & T.Value & Sig. \\
\hline \multirow{2}{*}{ ( Q1) } & post - test & 30 & 4.3667 & 0.71840 & \multirow{2}{*}{29} & \multirow{2}{*}{1.439} & \multirow{2}{*}{$\begin{array}{l}0.161 \\
\text { Not } \\
\text { Sig. }\end{array}$} \\
\hline & $\begin{array}{l}\text { retention- } \\
\text { test }\end{array}$ & 30 & 4.3000 & 0.70221 & & & \\
\hline \multirow{2}{*}{ ( Q2) } & post - test & 30 & 4.3333 & 0.94989 & \multirow{2}{*}{29} & \multirow{2}{*}{-0.254} & \multirow{2}{*}{$\begin{array}{l}0.801 \\
\text { Not } \\
\text { Sig. }\end{array}$} \\
\hline & $\begin{array}{l}\text { retention } \\
- \text { test }\end{array}$ & 30 & 4.3667 & 0.74201 & & & \\
\hline \multirow{2}{*}{ ( Q3) } & post - test & 30 & 4.5833 & 0.55837 & \multirow{2}{*}{29} & \multirow{2}{*}{-1.546} & \multirow{2}{*}{$\begin{array}{l}0.133 \\
\text { Not } \\
\text { Sig. }\end{array}$} \\
\hline & $\begin{array}{l}\text { retention } \\
- \text { test }\end{array}$ & 30 & 4.7667 & 0.50401 & & & \\
\hline \multirow{2}{*}{ ( Q4) } & post - test & 30 & 4.3500 & 1.07599 & \multirow{2}{*}{29} & \multirow{2}{*}{0.773} & \multirow{2}{*}{$\begin{array}{l}0.446 \\
\text { Not } \\
\text { Sig. }\end{array}$} \\
\hline & $\begin{array}{l}\text { retention } \\
- \text { test }\end{array}$ & 30 & 4.2333 & 1.13512 & & & \\
\hline \multirow{2}{*}{ ( Q5) } & post - test & 30 & 3.4333 & 0.84826 & \multirow{2}{*}{29} & \multirow{2}{*}{-1.349} & \multirow{2}{*}{$\begin{array}{l}0.188 \\
\text { Not } \\
\text { Sig. }\end{array}$} \\
\hline & $\begin{array}{l}\text { retention } \\
\text { - test }\end{array}$ & 30 & 3.6833 & 1.32927 & & & \\
\hline \multirow{2}{*}{ ( Q6) } & post - test & 30 & 3.9000 & 1.06188 & \multirow{2}{*}{29} & \multirow{2}{*}{1.779} & \multirow{2}{*}{$\begin{array}{l}0.086 \\
\text { Not } \\
\text { Sig. }\end{array}$} \\
\hline & $\begin{array}{l}\text { retention } \\
- \text { test }\end{array}$ & 30 & 3.5333 & 1.25212 & & & \\
\hline \multirow{2}{*}{ Total } & post - test & 30 & 24.9667 & 3.44647 & \multirow{2}{*}{29} & \multirow{2}{*}{0.258} & \multirow{2}{*}{$\begin{array}{l}0.799 \\
\text { Not } \\
\text { Sig. }\end{array}$} \\
\hline & $\begin{array}{l}\text { retention } \\
\text { - test }\end{array}$ & 30 & 24.8833 & 4.36618 & & & \\
\hline
\end{tabular}

The previous table (4) proves that there is no statistically significant difference between the mean score of the experimental groups each sub question and the total score of the post and Retention vocabulary tests. Although the mean scores of the post test (24.9667) are bigger than the mean scores of the retention test (24.8833), there is no statistically significant difference between the mean
Results of testing the third hypothesis that dealt with the differences between the mean score of the experimental groups post and Retention vocabulary tests are shown in the following table.

grificant difference between the mean the control group in recalling vocabulary.


This means that after 2 weeks of finishing the experiment, students still retained the amount of vocabulary they gained and / or developed during the experimental treatment.

Hence, retaining the previous words can be attributed to the proposed treatment. So, the third hypothesis of the study is verified.

\section{Results}

The present study led to the following findings:

1- Using vocabulary learning strategies (vocabulary notebook and PAVE) was effective in developing EFL $1^{\text {st }}$ secondary Institute students' vocabulary learning. This can be assured by these points:

- The experimental group students outperformed the control group students in the post vocabulary test.

- The experimental group students' mean score in the post - administration of the vocabulary test was much better tha their mean score in the pre- administration of the test.

2- Using vocabulary learning strategies (vocabulary notebook and PAVE) was effective in retaining the same amount of vocabulary they learned even after two weeks from finishing the experiment. This can be assured by this point:

- The experimental group students' mean score of the retention test was as good as their mean score of the post test. So, there does not seem to be much difference between the students' level of the vocabulary tests after the direct application of the vocabulary learning strategies or after 15 days.
The above- mentioned results are very consistent with the findings of many studies such as Walters \& Bozkurt (2009); Centenario (2013); Kömüra*\& Özdemira (2015) and Vela \& Rushidi (2016). These studies concluded that students of the experimental group who participated in the vocabulary notebook program performed better than the control group in terms of vocabulary acquisition. Thus, these findings proved that vocabulary notebooks are an effective tool that can be implemented in an EFL classroom.

Furthermore, findings of the current study go in line with the results of D'Onofrio (2009); Howell (2012); Mistique (2014) and Susilo (2016) which proved that PAVE strategy is effective in producing increasing vocabulary recall in students.

It can be noticed that these strategies helped raise the students' interactivity and participation as well as their motivation to learn. They also helped them to enjoy and love learning vocabulary. They also enabled them to understand and remember the meaning of words to be easier. The students got higher score after they were taught by using these strategies. PAVE and vocabulary notebook strategies were found to create a learning environment that promotes better learning opportunities for English language learners. Therefore, incorporating them in EFL vocabulary instruction could result in improving not only students' vocabulary learning but also their retention of these targeted new vocabulary items.

\section{Conclusions}

With reference to the results of the study, the following points were concluded:

Using a combination between the picture and the written word associated with the context in which it appears in teaching vocabulary made a great development in students' vocabulary learning and increase students' motivation. One of the best and simplest ways for 
students to retain new words meaning effectively is to review what they have learned regularly. It is also important for students to learn words in their context which helps their brain to form images and associate the word to other words. Also if they link a given word with an image, they will remember it better.

When students take notes on a lesson, they are developing their own independence, which could build their confidence in their ability to act independently of the teacher. They became autonomous and active learners. All mentioned ways can be achieved when adopting PAVE and vocabulary notebooks strategies in teaching vocabulary. These strategies can overcome students' difficulties in memorizing new words, writing those words in correct spelling and retrieving them in other situations.

The present study proved that PAVE and vocabulary notebook strategies are effective in enhancing vocabulary learning, gaining students' attention and activating students' prior knowledge. They also supported students' active involvement in vocabulary learning. They also helped students organize new vocabulary linking its form with its meaning in a way that helped them retain the new words in their long term memory and perform well in vocabulary learning tests.

\section{Recommendations}

Based on the results and conclusions of this study, the following recommendations were offered:

1. Vocabulary notebook and PAVE strategies are recommended to be used as a framework for enhancing vocabulary learning with secondary school students.

2. EFL teachers and trainers should make use of PAVE templates and notebook strategies as a method that could help long-term retention of vocabulary.
3. Vocabulary notebook strategies should be applied from the primary stage to the secondary stage. PAVE template should be drawn inside the notebook in the secondary stage.

4. Using variety of vocabulary evaluation activities inside the class should be recommended.

5. Other notebook formats which contain several vocabulary learning strategies that are related to discovering and enriching knowledge of word meanings should be explored.

6. Pronunciation- related activities should be added to help students retain more via the visual and sound cues.

7. Teachers should prepare printed pictures for the new words if the students can't draw while completing PAVE templates.

8. Students should be allowed to choose and personalize the word learning strategies they feel most comfortable with.

9. Students should be best trained to use their dictionary well.

10. Students should be trained on how to organize their vocabulary notebook.

11. Course designers should consider the inclusion of many exercises of guessing new words meaning from context to encourage students to have confidence in their abilities to discover meanings on their own.

12. Course designers should also provide a part at the end of the book. This part contains some PAVE templates students complete in order to be trained how to be self-independent exploring the meaning and using the dictionary.

13. The ministry of education should encourage teachers to apply and use PAVE and vocabulary notebooks inside the classroom 
Suggestions for Further Research

The following ideas may be considered

for further researches:

1. Investigating the effectiveness of individual vocabulary notebook and PAVE strategies on different language skills.

2. Investigating the effectiveness of PAVE and vocabulary notebook strategies on developing prep stage pupils' vocabulary learning.

3. Investigating the effectiveness of vocabulary notebook strategies on improving students' pronunciation.

4. Investigating the effectiveness of CAIVE vocabulary notebook template on improving vocabulary acquisition and retention.

5. The role of some vocabulary notebook strategies in improving primary stage vocabulary and grammar learning.

\section{References}

1. Centenario, L. L. (2013). Vocabulary notebooks: a tool to enhance memory or a memories notebook? Post- graduate M.Ed. EFL teachers. PP. (1-30). [On line] available:

2454/9823/http://academicae.unavarra .es/bitstream/handle/ Documento $\% 20$

2. Daloglu, A., Baturay, M., \& Yildirim, S. (2009). Designing a constructivist vocabulary learning material. In Handbook of research on e-learning methodologies for language acquisition (pp. 186-203). IGI Global.

3. D'Onofrio, G. (2009). The role of vocabulary notebooks in the retention and use of new words (Doctoral dissertation, Concordia University). April: pp. (1-105).

4. English Language Skills (Troy) (2011).Improve Your Question and Answer: Vocabulary Retention, June 9. [On
Line]:

http://english

language-skills.com/item/142-

vocabulary retention.htm

5. Fazeli, S. H. (2012). The Exploring Nature of Vocabulary Acquisition and Common Main Gaps in the Current Studies of

Vocabulary Acquisition. ISSN 19302940. Online

Submission, 12(3), 175-189.

6. Howell, G. (2012).Vocabulary Strategies for a Fourth Grade Classroom. Online Submission. Marygrove College, September 7, pp.1-39. [On Line] available:

7. http://files.eric.ed.gov/fulltext/ED5373 61.pdf

8. Kömüra,S. *\& Özdemira,P.(2015) . The Effects of Keeping Vocabulary Notebooks on Productive Academic Vocabulary Growth. GlobELT: An International Conference on Teaching and Learning English as an Additional Language, Antalya Turkey: Procedia - Social and Behavioral Sciences, 199, 3 August , 666 - 674, [On line] available:

http://www.sciencedirect.com/science/ article/pii/S1877042815046157

9. Lampariello, L. (2012). Forget it: the secret of remembering words. April 11, 13:41, Retrieved: May 29, 2016, 2:49am, [On Line] available: http://www.thepolyglotdream.com/for get- it-the-secret-of- rememberingwords/

10. Miami-Dade Public County Schools. (2000). Wild about words: A teacher's desktop vocabulary handbook. Bureau of Elementary, Secondary and Workforce Development Education, Division of Language Arts/Reading. Miami, Florida, summer, (1-178).

11. Mistique N. \& Hernandez (2014). Expanding vocabulary and improving comprehension through the use of 


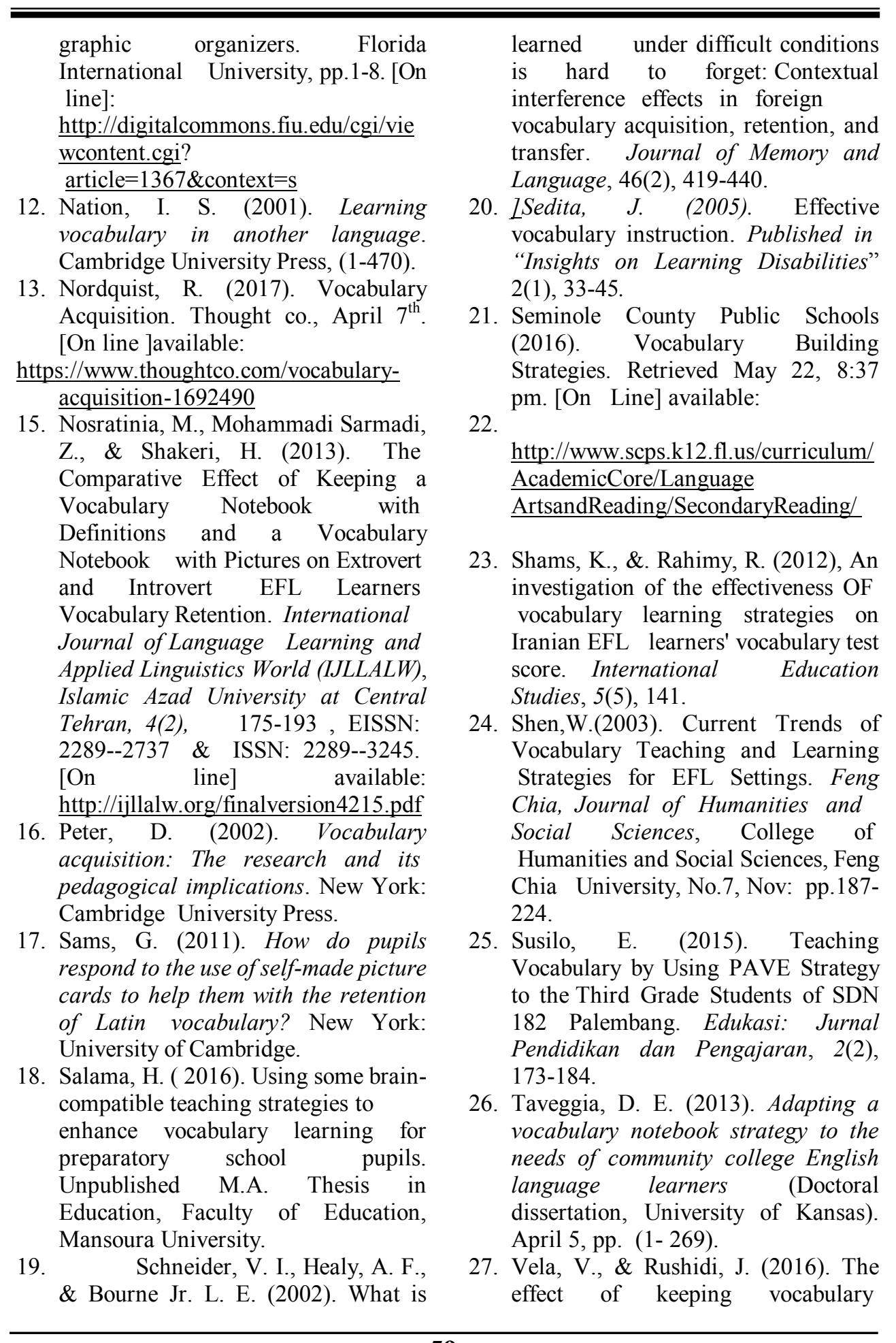


notebooks on vocabulary acquisition and learner autonomy. ProcediaSocial and Behavioral Sciences, 232, 201-208.

28. Walters, J. \& Bozkurt,N.(2009). The Effect of Keeping Vocabulary Notebooks on Vocabulary Acquisition. Language Teaching
Research, Bilkent University and Zonguldak Karaelmas University, 13April , 13(4), 403-423.

29. Yoshii, M. \& Flaitz, J. (2002).Second language vocabulary retention : The effect of text and picture annotation types. CALICO Journal, vol.20 (1): 33-58. 